Article

\title{
Frame Analysis of ENGO Conceptualization of Sustainable Forest Management: Environmental Justice and Neoliberalism at the Core of Sustainability
}

\author{
Nenad Šimunović ${ }^{1, *}$, Franziska Hesser ${ }^{1}$ and Tobias Stern ${ }^{2}$ (D) \\ 1 Wood K Plus (Kompetenzzentrum Holz GmbH), Market Analysis and Innovation Research Team, \\ Feistmantelstraße 4, 1180 Vienna, Austria; f.hesser@wood-kplus.at \\ 2 Institute of Systems Sciences, Innovation and Sustainability Research, University of Graz, Merangasse 18/1, \\ A-8010 Graz, Austria; tobias.stern@uni-graz.at \\ * Correspondence: n.simunovic@wood-kplus.at; Tel.: +43-1-47654-73513
}

Received: 30 June 2018; Accepted: 22 August 2018; Published: 4 September 2018

check for updates

\begin{abstract}
Normative judgments on sustainability underpin concepts that shape the supply scenarios of timber consumption. The modern understanding of sustainable forest management is shaped by a diverse spectrum of social demands, going beyond the principle of sustainable yield management. Rival stakeholders compete to incorporate their ideas and interpretations of sustainable forest management into policy institutions. Environmental non-governmental organizations (ENGOs) have emerged as one of the dominant stakeholders in the forest-based sector. We set out to explore ENGO-specific conceptualizations of sustainable forest management and investigate differences in understanding among various ENGOs. By conducting a frame analysis of ENGO press releases, we identified two master frames: environmental justice and environmentalist frames. A difference in the emphasis placed on procedural and distributive justice as well as a different standpoint in the commons versus commodity debate emerged as the main divergences between the master frames. The results of our study demonstrate how the differences between the master frames underpin different conceptualizations of sustainable forest management. On the one hand, the ENGOs associated with the environmental justice master frame advocate for the broader implementation of community forest management based on power-sharing. On the other hand, the ENGOs associated with the environmentalist master frame promote a wide range of approaches associated with ecosystem management and social forestry paradigms. Moreover, the ENGOs associated with the environmentalist master frame challenge the concept of sustainable forest management as defined by the Helsinki and Montreal process by advocating for ecosystem management. The ENGOs associated with the environmental justice master frame reject the mainstream concept of sustainable forest management in any guise. Future research on ethical issues underlying forestry concepts may provide more conceptual and operational clarity for both forest managers and policy-makers.
\end{abstract}

Keywords: sustainable forest management; environmental justice; NGO; forestry; sustainability science; frame analysis; master frame

\section{Introduction}

Although proclaimed "dead" [1] and "useless" [2], sustainability is beyond doubt one of the most relevant concepts in contemporary society. The discourse on sustainability profoundly influenced an understanding of sustainable forest management (SFM) [3]. The understanding of sustainability in the forest-based sector (FBS) is actor-specific [4]. A modern understanding of SFM goes beyond 
the principle of sustainable yield management and is shaped by a spectrum of social demands $[5,6]$. Normative judgments on sustainability underpin concepts such as a safe operating space, which are employed to estimate sustainable timber production scenarios [7,8]. SFM became, therefore, a contested concept, and rivalling stakeholders competed to incorporate their ideas and interpretations of SFM into policy institutions $[9,10]$.

Non-governmental organizations (NGOs) emerged as one of the key stakeholders in the FBS [11]. NGOs have strongly influenced forest or forest-related policy areas or strategies at international, national or regional level in various countries [12,13]. Environmental activism has also substantially influenced both the raw material supply and markets of the FBS [14]. The impact of NGO advocacy is most highly tangible with regard to the application of corporate social responsibility (CSR) practices. FBS companies made substantial changes in their organizational systems only after receiving pressure from NGOs and economic stakeholders [15,16]. Nylund and Kröger [4] suggested that differences in prioritization and framing of sustainability and related notions like environmental justice elicit different conceptualizations of sustainability between the pulp and paper industry, on the one side, and local communities and NGOs on the other.

Environmental justice is, like sustainability, a multifarious concept [17]. In general, the concept of environmental justice examines the equity of principles regulating a distribution of environmental benefits and burdens. Some researchers [18] have criticized the current mainstream understanding of sustainability by suggesting that a stronger emphasis must be placed on an environmental justice to ensure that sustainability becomes a "just sustainability". A distinction made between distributive and procedural justice is central to the different perceptions of environmental justice [17]. The former questions how just the generation and the allocation of environmental benefits and burdens are while the latter questions the fairness of the environmental decision-making processes [17,19]. Moreover, stakeholders' perceptions of procedural and distributive justice determine the acceptance of forest policies. Procedural justice (operationalized as an acceptance of decision-making processes related to forest management) and distributive justice (operationalized as acceptance of forestry operations) are some of the main explanatory factors of stakeholders' perception of the legitimacy of a forest policy [20]. A higher perception of legitimacy leads to an acceptance of a forest policy [21].

Considerations related to distributive and procedural justice in the FBS are especially prominent in the ongoing debates over the neoliberalization of forest governance [22,23]. A neoliberal, environmental governance strongly relies on the ethical responsibility of consumers and corporations; hence, it encompasses a patchwork of market-based regulatory bodies, including public-private partnerships, multi-stakeholder initiatives, NGOs and voluntaristic mechanisms [24-26]. The establishment of certification schemes, such as the Forest Stewardship Council (FSC), represent an example of marketization, a type of a neoliberal resource governance reform [27,28]. According to Bakker [27], a commons versus a commodity debate lies at the core of the discussion between proponents and adversaries of neoliberal environmental governance. NGOs have taken distinctly different standpoints in the debate on the neoliberalization of environmental governance. Some strongly reject it [18], while others facilitate the further expansion of market-based governance mechanisms [25].

NGOs strive to change the existing practices of the FBS by framing public opinion through the media [14]. Different definitions and understandings of sustainability can hinder further development of the FBS. For example, Knauf [29] demonstrates how the definitions, and the operationalization of sustainability indicators within the "strong sustainability" and "sustainable buildings" discourse in Germany limit the raw material base and marketing opportunities of the FBS.

The literature review revealed a gap considering the understanding of NGOs' specific conceptualization of SFM. So far, the research has focused on conflicts between NGOs and other stakeholders over international forest policy and corporate social responsibility $[4,12,14]$. However, it remains unclear whether the conceptualizations of SFM differ among various NGOs. Gaining a better understanding of the divergences among NGOs can provide additional knowledge regarding the issues and values that underpin the different conceptualizations of SFM. As such, this further contributes to the understanding of origins of conflicts over forest management. 
In this study, we employed a frame analysis of NGO press releases to elucidate the NGO-specific conceptualization of SFM, as well as to investigate differences in understanding among various environmental non-governmental organizations (ENGOs). Based on the literature review, we particularly considered the differences in the emphasis placed on distributive or procedural justice and those related to the commons versus commodity debate. Because normative ideas which underpin resource management decisions, like sustainability, are most highly evident in the suggestions that prescribe how the world should be [30], we focused on NGO propositions with respect to silvicultural systems and forest governance models to identify NGO-specific conceptualizations of SFM.

\section{Methodological Framework}

\subsection{Frame Analysis and Master Frames}

The frame analysis has been primarily employed by sociologists, however, it has been increasingly applied to study natural resource management and environmental conflicts [31,32]. The frame analysis is an interpretivist research method that can be used to investigate multiple understandings of a concept [33,34]. The groundwork of frame analysis was laid by Erving Goffman [35]. A plethora of scientific disciplines have picked up on the concept of frames and further adapted it [36]. All of the theoretical frameworks include the following two core tasks of a frame [33,36]:

(1) Organization of an experience: Frames provide a domain for a discussion and determine which issues are relevant and which are not.

(2) Bias for action: Frames suggest solutions for the identified issues and provide motivation for the conduct of a proposed solution.

Because the definition of SFM requires both tasks to be carried out (organization of experience and bias for action), a frame analysis is a suitable method that can be used to conduct an investigation of stakeholder-specific conceptualization of SFM.

Both policy [37] and social movement scholars [38] consider frames to be grounded in institutions and to be closely related to their interests. Accordingly, actors emphasize specific information and strive to gain acceptance for their definition of a problem to obtain more power by persuading other actors to perceive the problem in the same manner [37,39]. Therefore, we applied an approach to the frame analysis that is theoretically grounded in social movement theory [38,40].

The social movement theorists Benford and Snow [38] wrote of collective action frames, which have the following core features:

(1) Diagnostic-identifies a problem and attributes a blame to a cause or a culpable agent.

(2) Prognostic - suggests a solution to the identified problem (Levinger and Lytle [41] consider the term "prescriptive framing" to be more suitable for this frame feature because the term "prescriptive" is believed to better capture the sense of a demand for a specific action. We decided to apply the term "prognostic" because it is predominantly used in the reviewed literature [42-44] and it is the term used by the original authors).

(3) Motivational-provides grounds for the conduct of the proposed solution.

To conduct a higher level of analysis, Benford and Snow [40] proposed the concept of master frames. Master frames have the same core features as collective action frames, but they represent a generic type of a collective action frame that has expanded so greatly in scope and influence that it shapes and guides the activities of other organizations [40]. Benford and Snow originally developed the concept of master frames to explain the observation that social movement organizations cluster in time periods when the structural conditions for the mobilization of people are not optimal and the resources needed to meet the goals of social movement organizations are limited [45]. In addition to the core framing features, Benfored and Snow [40] identified three main variable features of the master frames to facilitate their analysis: attributional orientation, articulational scope and mobilizing potency. 
Attributional orientation describes whether the blame for the identified problems is internalized or externalized [40]. Articulational scope describes whether the rhetoric employed within a master frame is elaborate (universalistic and allowing for interpretative flexibility) or restricted (particularistic and organized around a narrow band of ideas) [40]. Mobilizing potency describes the likelihood of a master frame to mobilize support in a general public [40]. Taylor further developed the works of Benford and Snow and proposed a magnitude of change as another variable feature of a master frame [46]. The magnitude of change depicts the severity of change required by the solutions proposed in the prognostic frame feature [46]. In this study, we applied a heuristic device based on the attributional orientation, articulational scope and magnitude of change to identify different NGO master frames. Table 1 presents descriptions of the variables and respective sources.

Table 1. Heuristic device employed to identify master frames based on the variable features of master frames. Based on Benford and Snow [40] and Taylor [46].

\begin{tabular}{|c|c|c|}
\hline Variable Feature & Variable Description & Source \\
\hline Attributional orientation & $\begin{array}{l}\text { A direction in which blame is assigned for the diagnosed } \\
\text { problems and responsibility for the conduct of proposed } \\
\text { solutions is attributed. This can be internal or external. }\end{array}$ & [40] \\
\hline \multirow{3}{*}{ Articulational scope } & $\begin{array}{l}\text { A linguistic code of a master frame, its style of speech and } \\
\text { orientation with respect to meaning: }\end{array}$ & \multirow{3}{*}{ [40] } \\
\hline & $\begin{array}{l}\text { Restricted-tightly organized around a narrow band of ideas, } \\
\text { providing little interpretative flexibility. Particularistic with } \\
\text { respect to meaning and social structure. }\end{array}$ & \\
\hline & $\begin{array}{l}\text { Elaborate-syntactically flexible, organized around wide range } \\
\text { of ideas, allowing an interpretative flexibility. Universalistic } \\
\text { with respect to meaning and social structure. }\end{array}$ & \\
\hline \multirow{5}{*}{ Magnitude of change } & A level of change required by a social movement organization: & \multirow{5}{*}{ [46] } \\
\hline & Alternative-seeks partial change in individuals; & \\
\hline & Redemptive-seeks total change on an individual level; & \\
\hline & Reformative-seeks incremental change on a system level; & \\
\hline & $\begin{array}{l}\text { Transformative-seeks broad and systemic changes in the social } \\
\text { structure and ideological foundation. }\end{array}$ & \\
\hline
\end{tabular}

In our study, we did not consider the mobilizing potency. The mobilizing potency describes the likelihood that a master frame mobilizes support in a general public based on the master frame's articulational scope and the characteristics of those receiving a framed message. Since the aim of the study was to understand how NGOs conceptualize SFM and not whether specific framing of SFM is likely to mobilize support among a specific group of message recipients, the mobilizing potency was considered to be beyond the scope of the study.

\subsection{Neoliberal Environmental Governance and the Debate on Commons vs. Commodity}

Neoliberal environmental governance strives to minimize the role of governments and relies on a complex framework of voluntary, market-based mechanisms [25]. According to Bakker [27], the commons versus commodity debate lies at the core of the discussion between proponents and adversaries of the neoliberal environmental governance. Commodification represents one of the main types of the neoliberal governance methods. A commodification is understood as a creation of an economic good by applying mechanisms that appropriate and standardize a class of goods or services, enabling them to be sold at a price determined through market exchange [27].

To facilitate the analyses of activism and advocacy, Bakker provided a typology of market environmentalist reforms and of the commons versus commodity debate in water management [27]. 
To adapt Bakker's typology so that it was applicable to forest management, we adapted it by changing the goals of resource management as a commodity from "efficiency and water security" [27] to "efficiency and ecosystem services security". Table 2 presents the adapted typology. We applied the typology to explore if and how the master frames of NGOs differ with respect to the commons versus commodity debate and investigate whether different standpoints in the debate influence different conceptualizations of SFM.

Table 2. Typology of the commons versus commodity debate, adapted from Bakker [27] for forest management.

\begin{tabular}{ccc}
\hline & Commons & Commodity \\
\hline Definition: & Public good & Economic good \\
Regulation: & Command and control & Market-based \\
Goals: & Social equity and livelihoods & Efficiency and ecosystem-services security \\
Manager: & Community & Market \\
\hline
\end{tabular}

\subsection{Forest Management Paradigms}

According to Vucetich and Nelson, normative ideas which underlay environmental decision making, like sustainability, can be observed in the statements that suggest how the world should be [30]. Therefore, to elucidate which type of forest management is deemed most desirable and, hence, sustainable by the analyzed NGOs, we compared the prognostic frame features of the master frames against the background of the main forest management paradigms identified by Winkel in the Pacific Northwest region of the United States of America (USA) [47]. The forest management paradigms describe core patterns, policy problems, governance modes and most influential actors of specific forest management arrangements [47] (see Table 3). Based on the results of a review of the scientific literature describing the historical development of forestry concepts and approaches to forest management [3,48-51], we argue that the selected four paradigms identified by Winkel currently represent the most relevant forest management paradigms worldwide.

Table 3. Typology of forest management paradigms based on [3,47-51].

\begin{tabular}{cl}
\hline Forest Management Paradigm & \multicolumn{1}{c}{ Description } \\
\hline Industrial forestry & $\begin{array}{l}\text { The main management objective is timber production and it is maximized in order to } \\
\text { generate the greatest possible profit. The most influential actors are the timber industry } \\
\text { and investment funds. Forest policy focuses on increasing the competitiveness of } \\
\text { timber industry, and a governance arrangement is increasingly liberalized. }\end{array}$ \\
\hline Sustainable yield management & $\begin{array}{l}\text { Timber production is the core management objective. Harvest level is constrained by } \\
\text { the periodical prescribed yield. Wood production and recreation are the main forest } \\
\text { functions. The most influential actors are the timber industry, forestry scientists, and } \\
\text { forest management service. }\end{array}$ \\
\hline Multiple-use forestry & $\begin{array}{l}\text { Timber production and maximal revenue from sales of other services are the main } \\
\text { management objectives. A broader range of ecosystem services is considered but } \\
\text { provided only "in the wake" of timber production. Forest management is based on the } \\
\text { sustainable yield management. The most influential actors are the timber industry, } \\
\text { forestry scientists, and forest management service. }\end{array}$ \\
\hline Ecosystem management & $\begin{array}{l}\text { The main objective of management is the maintenance of the biological integrity and } \\
\text { increase in the security and efficiency of provision of ecosystem services. Forest } \\
\text { management relies on conservation biology knowledge. The most influential actors are } \\
\text { ecologists, environmentalist organizations, and national forest service. }\end{array}$ \\
\hline $\begin{array}{l}\text { Local communities are integrated into forest management practices and } \\
\text { decision-making process. The main objectives are determined through participatory } \\
\text { processes. Local knowledge is prioritized and decision-making decentralized. Social } \\
\text { activists, social scientists, and local/regional actors are the most influential actors (local } \\
\text { communities, politicians, entrepreneurs etc.). }\end{array}$ \\
\hline
\end{tabular}




\subsection{Empirical Approach}

\subsubsection{Press Releases}

Press releases were used as an empirical base for the analysis. Press releases are considered to be a key instrument for achieving publicity [52]. Press releases are publications written to provide information for journalists in the hope that they will be passed on to the general public [53]. Unlike newspaper articles, press releases do not only provide information to the general public, but are also characterized by their detectable positive bias towards the publishing institution [52]. Therefore, apart from being informative, press releases have a propagandistic purpose [52,53]. For example, Gilpin showed how Italian multinational Parmalat used press releases to construct a narrative of victimization in the public eye as it was approaching its bankruptcy [54]. Hence, it can be assumed that organizations frame contested concepts (such as SFM) in press releases according to their own interest.

Frame analyses of press releases were applied to understand how organizations shape information that is publicized and how organizations portray their initiatives to the general public [55]. The framing of public opinion through the media is one of the main strategies used by NGOs to change the existing practices of FBS [14]. Press releases and other written materials are some of the main diffusion channels used by NGOs to disseminate the information on CSR practices in FBS [56]. All of the above makes press releases a suitable material for the analysis of ENGO-specific conceptualizations of SFM.

\subsubsection{Sampling and Data Collection}

NGOs can be defined and categorized in different ways [12,57,58]. In this paper, we focus on ENGOs, which are groups that have been established independent of governments or corporations and that operate as non-profit organizations to promote environmental issues [14]. We use the term ENGOs to refer to the organizations analyzed in our study. We initiated our sampling by focusing on ENGOs that participate in the United Nations Forum on Forests (UNFF). United Nations' Economic and Social Council (UN ECOSOC) grounded UNFF as a policy forum that has the principal function of fostering a common understanding of SFM by maintaining a dialogue between the governments, international organizations, NGOs, and other major groups [59,60].

We initiated our sampling by conducting a query in a UN ECOSOC database. We employed the following criteria: Language(s): English; Consultative status: Special (UN ECOSOC awards the "special status" to NGOs that have a special competence in, and are concerned specifically with, only a few of the fields of activity covered by ECOSOC [61]); Forests-Major Groups: Non-governmental organizations (in the Agenda 21 [62], UN described nine major groups: women, children and youth, indigenous peoples, NGOs, local authorities, workers and trade unions, business and industry, scientific and technological community, and farmers. Major groups represent sectors of society that have to be integrated into the intergovernmental processes to foster progress towards sustainable development. The criterion "Forests-Major Groups" lists organizations participating in UNFF according to their allocation to a specific major group).

Out of 70 ENGOs resulting from the query, only four had a working press release archive available on their website that included press releases published in English. The FSC was excluded from the sample, because it is a multi-stakeholder initiative (we understand multi-stakeholder initiatives as: "voluntary and self-regulatory agreements between different constellations of stakeholders from different societal sectors, including businesses, civil society, governments, international organizations and sometimes academia" $[63,64])$, and the aim of the analysis was to investigate framing conducted by individual ENGOs. We then expanded the sample by applying a snowballing sampling technique [65]. We reached a data saturation point [65] after we had analyzed the eight ENGOs presented in Table 4.

We harvested press releases in a PDF format directly from the ENGO websites. We collected press releases that were published in the time period 2013-2017 to take stock of the current situation and because the available press release archives of some of the analyzed ENGOs only included press 
releases that dated back to 2013. Table 5 provides the list of analyzed ENGOs, the number of collected press releases, and the coded statements.

Table 4. Sample of analyzed environmental non-governmental organizations (ENGOs), number of collected press releases and analyzed statements.

\begin{tabular}{ccc}
\hline ENGO & Press Releases & Statements \\
\hline Fern & 48 & 169 \\
Friends of the Earth & 26 & 42 \\
Greenpeace International & 61 & 144 \\
Rainforest Alliance & 32 & 44 \\
The Global Forest Coalition & 31 & 80 \\
The Nature Conservancy & 21 & 41 \\
World Rainforest Movement & 15 & 69 \\
World Wildlife Fund & 117 & 241 \\
\hline TOTAL & 351 & 830 \\
\hline
\end{tabular}

Table 5. An overview of coding dimensions with their respective descriptions and related framing features.

\begin{tabular}{ccc}
\hline Coding Dimension & Description & Framing Feature \\
\hline Problem & The issues perceived as a problem in the analyzed statement. & Diagnostic \\
Reason/Cause & A reason, cause, or a culprit to whom a blame for the identified problem is assigned. & Diagnostic \\
Solution & An action or a remedy proposed as a solution to resolve a problem. & Prognostic \\
Motivation & A rationale for an engagement in a proposed ameliorative action. & Motivational \\
Location & A geographical location to which a statement refers. & \\
\hline
\end{tabular}

\subsubsection{Coding Framework}

Frames can be identified out of texts produced by actors [37,39]. Applied analytical approaches are diverse, ranging from purely qualitative to quantitatively supported approaches [66]. Qualitative research is suitable when the goal is to capture various meanings of a concept and describe subjective viewpoints $[67,68]$ We applied a qualitative approach to frame analysis based on the Jensen and Johnsen $[36,42,69]$. First, we identified relevant press releases by using the following keywords: forest *, timber *, lumber *, logging, fiber, and wood. The coding of the analyzed material was based on a two-stage approach.

The first stage is called "open coding". During the open coding stage, we carefully read the press releases to identify relevant statements and made extensive memos with respect to the research aims and the theoretical framework.

The second stage is called "focused coding". During the focused coding stage, the meaning of the statements is coded and the frames are synthesized. Before we started with the focused coding, a coding framework was developed based on the core framing features identified by Benford and Snow [38]. Coding dimensions "problem" and "cause/reason" correspond to the diagnostic frame feature. The coding dimension "solution" corresponds to the prognostic frame feature. The coding dimension "motive" corresponds to the motivational frame feature. Together with these four coding dimensions corresponding to the core framing features, we include the coding dimension "Location" into our coding framework to differentiate between the statements addressing different geographical locations. Table 4 provides an overview of the applied coding dimensions, their descriptions and respective framing features.

For each coding dimension, we awarded codes inductively by following a "meaning coding" [70] approach. The aim of meaning coding is to go beyond the manifest content of a text and code the central themes of each statement with respect to each coding dimension. We selected a statement as a unit of analysis. We apply a definition of a statement according to Day and Page "a series of words containing information which could be classified into a single category" [71]. A statement is commonly 
applied as a unit of analysis in frame analysis [43,44]. We coded and analyzed the press releases using the scientific software for qualitative data analysis Atlas.ti. All coding dimensions were not necessarily present in a single statement.

To identify the most strongly emphasized issues in the statements, we considered the frequency of the codes. We synthesized the frames by observing the patterns between the codes and clustering statements that construct arguments in the same manner. The master frames, therefore, comprise thematically reinforcing clusters of statements that perform the core framing features by promoting a particular problem definition, causal interpretation, moral evaluation and, in such a manner, endorse a specific course of action. The differences between the master frames were identified by comparing the meaning of the coded statements against the descriptions of the variable master frame features presented in Table 1.

We applied the same approach to identify which type of forest management was deemed sustainable by ENGOs affiliated with different master frames and identify differences with respect to the commons versus the commodity debate. In this case, we focused only on the content of the statements in which we observed the prognostic frame feature. We focused on the statements in which we observed the prognostic frame feature because normative ideas which underpin decisions on environmental management, such as sustainability, are evident in the statements that prescribe how the world should be [30]. The content of the statements was compared against the background of the typology of the commons versus a commodity debate presented in the Table 2 and the typology of the forest management paradigms presented in Table 3.

\section{Results}

By analyzing ENGO press releases, we identified two master frames employed by the ENGOs (environmentalist master frame and environmental justice master frame). Table 6 provides a comparative overview of the identified ENGO master frames based on their variable features. In the first two sections below, we describe the identified master frames with respect to their framing features (diagnostic, prognostic and motivational) and compare them based on the variable features of master frames (attributional orientation, articulational scope, magnitude of change). We also illustrate the identified master frames by providing canonical examples of statements featured in the analyzed material.

In the following two sections, we demonstrate how different characteristics of the master frames contribute to different conceptualizations of SFM. Lastly, by highlighting the differences between the master frames, we provide a conceptual model, which illustrates how differences between the master frames underpin contrasting conceptualizations of SFM. 
Table 6. A comparative overview of the identified ENGO master frames based on their variable features.

\begin{tabular}{|c|c|c|c|c|c|}
\hline Master Frame & ENGOS & Attributional Orientation & Magnitude of Change & Articulational Scope & Geographical Scope \\
\hline & & External. & Transformative. & Restricted. & \multirow[b]{2}{*}{$\begin{array}{c}\text { Predominantly } \\
\text { Global South and } \\
\text { developing countries }\end{array}$} \\
\hline Environmental justice & $\begin{array}{l}\text { World Rainforest } \\
\text { Movement, Friends } \\
\text { of the Earth, Global } \\
\text { Forest Coalition. }\end{array}$ & $\begin{array}{l}\text { Present economic system and } \\
\text { the development paradigm are } \\
\text { highlighted as the main culprits } \\
\text { causing environmental and } \\
\text { social problems. }\end{array}$ & $\begin{array}{l}\text { Only a change of the underlying } \\
\text { socio-economic model and } \\
\text { a radical change of the } \\
\text { development paradigm may } \\
\text { bring about long-term solutions } \\
\text { to the environmental problems }\end{array}$ & $\begin{array}{l}\text { The language applied is } \\
\text { highly particularistic and } \\
\text { critical of social structure. } \\
\text { The breadth of the proposed } \\
\text { solutions and the number of the } \\
\text { culprits is limited. }\end{array}$ & \\
\hline \multirow[b]{2}{*}{ Environmentalist } & \multirow[b]{2}{*}{$\begin{array}{l}\text { World Wildlife Fund, } \\
\text { Greenpeace International, } \\
\text { Fern, Rainforest Alliance, } \\
\text { The Nature Conservancy. }\end{array}$} & Internal. & Reformational. & Elaborate. & \multirow[b]{2}{*}{ Worldwide. } \\
\hline & & $\begin{array}{l}\text { Individual actors (companies, } \\
\text { institutions, and governments) } \\
\text { within the existing socio-political } \\
\text { and economic system are blamed } \\
\text { as the main culprits. The ENGOs } \\
\text { often propose collaboration projects } \\
\text { with the culprits as a part of the } \\
\text { solution for the identified issues. }\end{array}$ & $\begin{array}{l}\text { Proposed activities are aimed at } \\
\text { improving the existing } \\
\text { production systems and } \\
\text { consumption patterns. }\end{array}$ & $\begin{array}{l}\text { The propositions are organized } \\
\text { around a wide range of ideas. } \\
\text { The language applied is } \\
\text { universalistic and allows for } \\
\text { interpretative flexibility. } \\
\text { The breadth of proposed } \\
\text { solutions is wide and there is } \\
\text { a large number of culprits. }\end{array}$ & \\
\hline
\end{tabular}




\subsection{Master Frame Environmental Justice}

The following ENGOs can be allocated with the environmental justice master frame: the World Rainforest Movement, Friends of the Earth, and Global Forest Coalition. The ENGOs associated with the environmental justice master frame strongly reject the concept of SFM in any guise. SFM is perceived as a fundamentally flawed concept. It is, therefore, labelled as a "myth" or a "nasty little euphemism that allows destructive and often illegal logging to continue with impunity":

"Sustainable forest management" allows an inherently destructive activity such as logging to continue with the promise of "keeping the forests standing". But the concession model, while beneficial to logging companies, is destructive for the forest and harmful for the communities for whom the forest provides a livelihood, especially for women. Even worse, the concept, backed up by numbers indicating that only a "small amount" of timber will be taken out, also serves as a "passport" for companies to enter into new forest areas and supposedly conserve these by just taking out a "few" trees" [72].

The crux of this critique lies in the perception of logging activities and presently dominant forest governance models as inherently leading to distributive injustice. Logging activities are believed to cause a shift in social power from the people to private companies through a commodification of forests.

"For these people who depend on forests, non-timber forest products like fruits, seeds and medicinal plants have a huge importance, as well as fishing, hunting and also agriculture". Peasants in forest areas traditionally practice agriculture based on knowledge transmitted over many generations, conserving, not destroying forests. Forests are fundamental for peasants to guarantee their food sovereignty. We oppose the increasing commodification of natural resources like forests, pushed by TNCs [transnational corporations] and mechanisms like REDD [United Nations Program on Reducing Emissions from Deforestation and Forest Degradation]" [73].

Likewise, any kind of forest certification further exacerbates the unjust social distribution of power, benefits, and harms generated by logging. Such a radical critique, which requires a complete rethinking of the SFM concept, is in accordance with the transformative character of the environmental justice master frame.

"RSPO [Roundtable on Sustainable Palm Oil] and FSC are not working to transform a heavily concentrated and unequal production model that provides cheap vegetable oil and fiber for global food, energy or pulp and paper industries into a localized model of small-scale production based on agroecological and social justice principles ... . They are about increasing the share of RSPO-certified palm oil and FSC-certified wood products and the safeguarding of corporate profits through providing a 'green' label to greenwash ultimately inherently unsustainable industrial monoculture plantations" [74].

By the same token, international organizations like the Food and Agriculture Organization (FAO) and World Bank are blamed as the main culprits for deforestation. The definition of forest employed by FAO and World Bank contribute to the unjust power distribution in society and deforestation because timber plantations are classified as planted forests:

"The present FAO definition benefits first and foremost corporate interests, especially the tree plantation and timber industries. These companies-national and transnational-exacerbate and often drive land and resource grabbing over territories of communities across the global South" [75].

Timber plantations represent the dominant issue with respect to the diagnostic frame feature. A wide range of both environmental and social concerns that are brought up, are related to the expansion and management of timber plantations. Among environmental issues, the negative impact of wood harvesting on biodiversity and climate change are the issues that are the most strongly emphasized. 
However, as with diagnostic framing, the prognostic feature can be tied to systemic causes. The rationale and motivation for the conduct of the proposed solutions are firmly grounded in the critique of a contemporary social structure and a dominant economic development paradigm:

"This federation is committed to environmental, social and gender justice and system change, which implies understanding the structural causes of environmental problems and to demand and build real solutions to realize people's rights.... The top priority for the next 2 years will be to mobilize people in all corners of the world for a radical change in our food and energy systems, as well as to collectively defend forest and biodiversity and challenge corporate power and the neoliberal architecture of free trade and investments agreements...Friends of the Earth International has started a system change process which focuses on analyzing and challenging the power and privilege granted by capitalism and patriarchy to global elites that endanger life on the planet as we know it" [76].

Although the scope of the proposed solutions is limited, their inherent goal is to cause a systemic change on a largest possible scale. Therefore, the environmental justice frame represents a transformative type of master frame. With respect to the location, the analyzed statements refer almost exclusively to the tropics and Global South. The attributional orientation of the environmental justice frame is external because the blame is always assigned to the economic and political system and its major representatives, while the authors portray themselves as acting outside the system boundaries. Lastly, the applied rhetoric is highly particularistic and tightly organized around a critique of neoliberalism and the dominant economic paradigm. The breadth of proposed solutions and actors to whom the blame is assigned are limited and both are, in essence, linked to systemic causes. Hence, the articulational scope of the master frame is restricted.

\subsection{Environmentalist Master Frame}

Five of the analyzed ENGOs could be allocated with the environmentalist master frame: the World Wildlife Fund, Greenpeace, Fern, Rainforest Alliance, and The Nature Conservancy. Tropical deforestation and degradation of ancient and endangered forests represent the dominant issues with respect to the diagnostic frame feature. Both dominant issues are associated with a wide scale of environmental and social concerns. Concerns about biodiversity degradation are commonly raised because high biodiversity levels are associated with the optimal provision of non-timber forest products (NTFPs) and ecosystem services:

"While there are several connections between biodiversity and healthy human life, the new report focuses on four areas specifically — those relating to medicinal drugs, microbial diversity, infectious diseases and mental health. It also outlines the role biodiversity plays in providing food, water and vital ecosystem services to communities worldwide, especially indigenous peoples, forest-dwellers, fisherfolk and others who are directly dependent on forests, rivers, lakes and oceans for their lives and livelihoods" [77].

Together with the social and environmental concerns, the spectrum of grievances also covers economic issues. The economic role of forests is described as a complex fusion of regulating, supporting, and provisioning ecosystem services. Hence, forests are conceived of as both a source of raw materials and a source of other environmental and social benefits:

"Forests are providing some of the most vital nature services that underpin the global economy and are critical for supporting the lives and prosperity of local people, communities and humanity globally. If protected and managed responsibly these key ecosystems can continue to provide economic and social benefits now and for future generations, while contributing to the local and global ecological balance essential to all life on Earth... Ultimately, this partnership is working to ensure that forests continue to be an ongoing sustainable source of fiber within a world enriched by extensive, resilient forest landscapes benefiting biodiversity, climate and human well-being" [78]. 
Among the proposed solutions, calls for environmental protection and conservation dominate the discourse. World heritage sites, high conservation value (HCV) and high carbon storage (HCS) sites, intact forest landscapes (IFLs), as well as more ambiguous categories such as primeval, natural, ancient, and virgin forests are all to protected from commercial use.

"It's not illegal to chop down the last critical forest landscapes, but it is brutal. That is exactly why we need a proper process for defining the areas in need of legal protection. The logging in these forest areas must stop now. We cannot engage in wordplay while harvesters are actively cutting down precious forested areas" [79].

However, the range of proposed solutions is broad and encompasses a vast spectrum of activities that range from improvements of forest management techniques to corrections of international trade agreements and requirements for improvements in the enforcement of national legal frameworks:

"Restoring forests on formerly forested lands, and avoiding further loss of global forests, are the two largest opportunities. Success depends in large part on better forestry and agricultural practices, particularly those that reduce the amount of land used by livestock. ... Meanwhile, improved forestry practices across expanded and existing working forests can produce more wood fiber while storing more carbon, maintain biodiversity, and help clean our air and water" [80].

As shown by the quotes above, both the diagnostic and prognostic frame features are broad in scope and not based on a single idea or concept. The applied rhetoric of the environmentalist master frame employs universalistic concepts like "responsible forest management", "environmental and social benefits" or "wellbeing", which allow for interpretative flexibility.

The blame for environmental harm is commonly assigned to an individual company or to an institution. For example, large pulp and paper companies operating in Southeast Asia are often singled out and targeted in ENGO campaigns. The proposed solutions attempt to decouple industrial practices from environmental harm by correcting and improving the production and consumption practices. Moreover, the proposed solutions do not address only a single actor, but generally require the investment of shared effort and collaboration between governments, private sector actors and members of civil society. Hence, the participation of multiple stakeholders in decision-making is almost universally demanded.

“We urge Indonesia's government to use the momentum of APP's [Asia Pulp and Paper] move to strengthen and extend the moratorium, starting with a review of all existing forest concessions. As a matter of urgency, the government should improve enforcement of forestry laws to help companies like APP implement their conservation policies. Only concerted action from government, industry and Indonesian civil society can finally turn the tide of extinction facing Sumatra's tigers" [81].

The environmentalist master frame has an internal attributional orientation because blame is assigned to individual actors within the present economic and socio-political systems, but never to a paradigm underlying the presently dominant economic and political models. Moreover, the environmentalist master frame assigns blame to a multitude of actors and proposes a wide range of solutions that require the cooperation of many actors, including the ENGOs themselves. The magnitude of change is reformative, because the solutions are generally proposed to correct or improve the present production systems and consumption patterns. The proposed solutions and identified problems are also associated with a broad range of issues and not based on a single idea (e.g., a critique of neoliberalism). Furthermore, the applied rhetoric is not particularistic and allows for an interpretative flexibility. Therefore, the environmentalist master frame has an elaborate, articulational scope. Lastly, although issues in Global South are more strongly emphasized, plenty of statements addressed issues in the Global North. The geographical scope is, therefore, worldwide. 


\subsection{Sustainable Forest Management and the Environmental Justice Master Frame}

Calls for more forest protection dominate the prognostic frame feature. However, the forest should be conserved by abandoning fence and fine conservation models and by shifting to forest management approaches based on traditional, customary practices and the recognition of indigenous land tenure rights.

"The customary practices of Indigenous peoples, local communities and women, and their traditional knowledge, do not only contribute to biodiversity conservation and restoration, they also form a cornerstone for ecosystem-based climate resilience. These practices almost always have very significant climate mitigation co-benefits and must be prioritized in any potential future climate deal" [82].

Together with the implementation of traditional forest management practices, the forest should be managed as a common pool resource. In such a manner, the commodification of forests and the related unjust distribution of social power can be prevented:

"Nature is a common good that we all share rights to and have responsibility over. It should be managed democratically by a commons-centered approach and not by a market based approach that takes power away from the people and gives more resources to those who can pay the most. Many organizations, scientists and people have come together through this statement to expose that the motive is profit, not conservation" [83].

The most desirable type of forest management is, hence, a small-scale, commons-centered approach, based on the customary practices and traditional knowledge of local communities. As such, it is exclusively associated with a social forestry management paradigm.

"It's clearly time we put the management of forests back in the hands of the communities who have managed them sustainably for generations", said Rojas. "False solutions like REDD+ cause incalculable harm. Community forest management is a collection of methodologies representing centuries of wisdom working with nature. Community forest management is climate-, biodiversityand people-friendly" [84].

Moreover, the transfer of property rights to local communities and their empowerment in the decision-making process are seen as safeguards against market and state failures in forest management. Based on the information mentioned above, we conclude that placing a specific emphasis on distributive justice, considering forests as common pool resources and endorsing extensive forest management techniques aimed at a provision of NTFPs are central considerations with respect to SFM within the environmental justice master frame.

\subsection{Sustainable Forest Management and the Environmentalist Master Frame}

Several forest conservation and forest management approaches occur in the prognostic frame feature of the environmentalist master frame without any of them being dominant. Which approach to forest conservation or forest management is desirable depends highly on contextual factors, such as geographical region, biodiversity value, carbon stocks and cultural value. Natural forest in the tropics, $\mathrm{HCV}$, and HCS sites as well as more ambiguous categories like ancient, primeval and virgin forest in other parts of the world are all to be strictly conserved.

Community forestry is commonly endorsed in areas populated by forest dependent and indigenous peoples. Therefore, forest management approaches associated with the social forestry management paradigm are considered to be the most desirable types of forest management in areas where local communities strongly depend on forests for their livelihoods and an income from forest management is essential for further social development. 
"Social Forestry is part of BFCP's [Berau Forest Carbon Program's] main strategies in the management of forest and other natural resources. Merabu is a model village in community-based natural resource management by applying an approach called "inspirational community actions to effect change" (SIGAP). This approach addresses the challenges villages face by helping to empower them to better protect and manage their forests and improve their livelihoods. Merabu will share its experience in managing forest sustainably and implementing green growth at the site level" [85].

Furthermore, ecoforestry is commonly proposed as an alternative to large-scale industrial practices in buffer zones of protected areas. Ecoforestry is associated with both ecosystem forest management and social forestry management paradigms:

"The Greenpeace flagship, Rainbow Warrior, sailed into the Indonesian province of Papua for the first time today as part of a global campaign to help protect the world's last ancient forests. Greenpeace is on a mission to protect the Paradise Forests, the last ancient forests in Asia Pacific, from illegal and destructive logging, and is launching an eco-forestry program in Papua to offer community-based forest management as an alternative to large-scale, industrial logging" [86].

However, together with the conservation and implementation of extensive approaches to forest management, "responsible" commercial forest management is also endorsed. "Responsible" commercial forest management should also be based on ecoforesry practices like selective logging:

"While there is an unquestionable need for formal protection of a representative portion of the region's and the world's most socially and environmentally important forests, the majority of the world's forests will remain outside of protected areas. Well-managed selective logging concessions can buffer protected areas, support healthy populations of rare or endangered species and benefit people. Responsible forestry, including both intensive commercial management and community forestry, has a key role to play in conserving global biodiversity, preventing illegal logging and providing economic and social benefits to society" [87].

Certification of commercial forest management is an obligatory requirement for a sustainable, commercial forest management. The FSC certification represents the only forest certification scheme that is endorsed by the ENGOs. The FSC certified forest management is associated with the ecosystem management paradigm:

"FSC is the best forest management assurance system available, and is recognized as the top level of commitment by leading environmental groups operating within the tropical forest industry. FSC certification ensures the forest management is (1) environmentally appropriate - protecting and maintaining natural communities and high conservation value forests (2) socially beneficial-respecting the rights of workers, communities and indigenous peoples and (3) economically viable — building markets, adding best value and creating equitable access to benefits" [88].

Accordingly, timber plantations are considered to be sustainable sources of wood, provided that they have not been established on previously deforested land and that the criteria for procedural justice have been fulfilled (e.g., a provision of a free prior and informed consent). The presence of such timber plantations is considered to alleviate market pressure from other socially and environmentally more valuable forests.

"For example, WWF's analysis shows that the amount of wood we take from forests and plantations each year may need to triple by 2050. According to FRA2015 [The Global Forest Resources Assessment 2015], plantations are expanding and supplying an increasing proportion of the world's wood. In the right place and managed sustainably, tree plantations can reduce the pressure to bring natural forest areas into production" [89]. 
Together with FSC certification, procedural justice is a crucial element of sustainable, commercial forest management. The decision-makers are urged to integrate a wide range of stakeholders into decision-making practices in order to avoid social conflicts over forest management practices:

"Industrial-scale agricultural concessions, many foreign-owned, are often allocated throughout West and Central Africa without proper land-use planning. This frequently generates social conflicts when forest clearance takes place without prior consent of local communities. This can result in severe negative ecological impacts and effects on endangered wildlife species as many concessions overlap with forest areas of high biodiversity value. "Governments need to urgently develop a participatory land use planning process prior to the allocation of industrial concessions, ... "Projects that are being developed without adequate community consultation and are located in areas of high ecological value should not be allowed to proceed and risk further social conflict and environmental damage" [90].

In conclusion, the exact conceptualization of sustainable forest management depends highly on contextual factors. Only forest management practices associated with social forestry and ecosystem forest management are perceived as sustainable. However, FSC certification and the achievement of procedural justice emerge as the main convergences between the forest management practices endorsed within the environmentalist master frame.

\subsection{Conceptual Model Depicting Differences in Conceptualization of SFM between the Master Frames with}

Figure 1 presents a conceptual model based on the results presented in the previous sections. The conceptual model depicts how different standpoints in the debate on the commodity versus commons and differences in the understanding of environmental justice influence different conceptualizations of sustainable forest management. For example, the ENGOs associated with the environmentalist master frame consider timber plantations to be sustainable sources of wood, provided that they satisfy the FSC environmental and social safeguards. Conversely, the ENGOs associated with the environmental justice master frame renounce any kind of timber plantation as a sustainable source of wood, because these contribute to distributive injustice. Furthermore, the ENGOs associated with the environmental justice master frame reject forest certification because it is considered to contribute to distributive injustice and commodification of forests. The ENGOs associated with the environmentalist master frame consider FSC certification to be the main means of transforming industrial forest management into sustainable forest management.

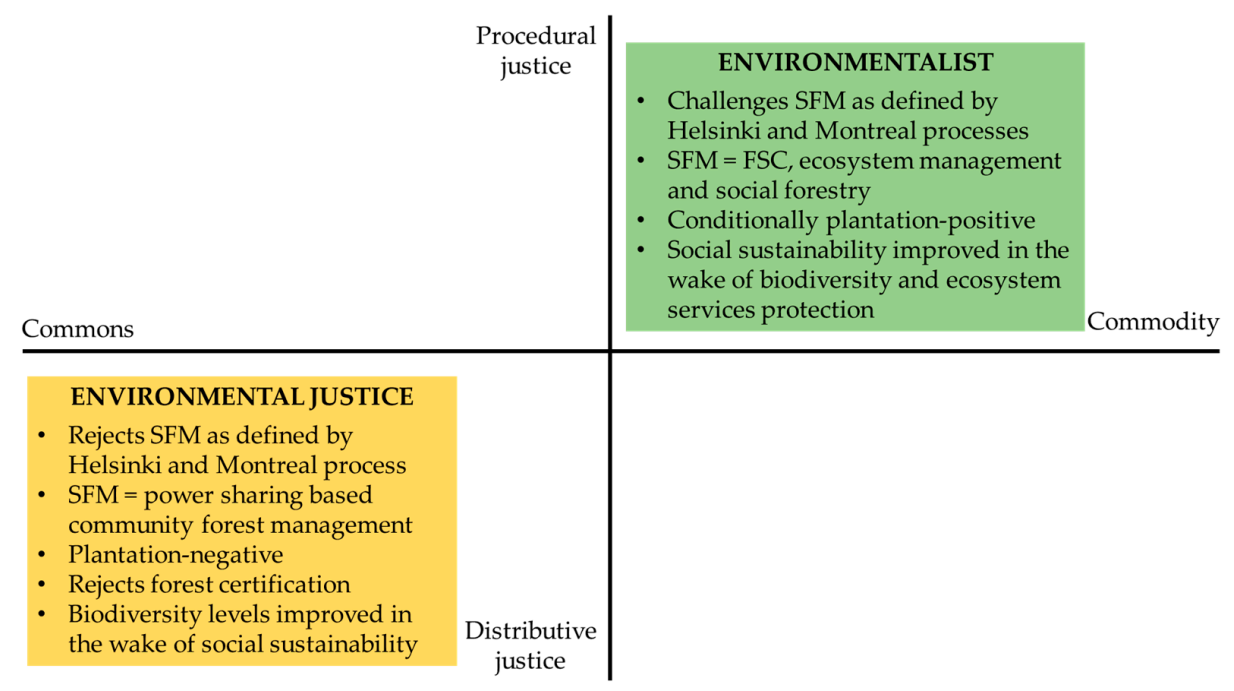

Figure 1. A conceptual model depicting different conceptualizations of sustainable forest management (SFM) with respect to main divergences between the master frames. 


\section{Discussion and Conclusions}

\subsection{Social Sustainablity and Conceptualizations of SFM in Forest-Based Sector.}

Social sustainability and environmental justice have prominent roles in both master frames. However, within the environmental justice master frame, distributive justice is central to the critique of forest management. Conversely, in the environmentalism master frame, the procedural justice is more emphasized. Despite the different foci, social sustainability and more specifically environmental justice strongly shape ENGO considerations of SFM regardless of the master frame.

According to Suterlütty and colleagues [91], social sustainability is one of the dominant foci of scientific research of SFM, and it is significantly more emphasized in the Global South. However, scientific research on CSR in the forest-based sector paints a different picture. Tuppura and colleagues [15] observed that social issues, like labor conditions and community engagement, have gained more attention in recent years in the forest-based sector. The latest reviews, however, show that both CSR activities [92] and research on CSR practices [93] in the forest-based sector predominantly focus on environmental responsibility. Nylund and Kröger [4] suggested that the differences in the emphasis on social sustainability and the understanding of what development means shape the conflicting conceptualizations of sustainability held by the pulp and paper industry and local NGOs in South America.

Our results empirically support such conclusions and provide a more detailed picture with respect to ENGO conceptualizations of sustainability in the forest-based sector. As pointed out by Nylund and Kröger [4], placing an emphasis on distributive justice and criticizing neoliberal economic policy are highly prominent concerns among the ENGOs. However, according to our results, such grievances are characteristic only of ENGOs associated with an environmental justice master frame, which have an explicit focus on the Global South. On the other hand, the ENGOs associated with the environmentalist master frame emphasize procedural justice, do not criticize the neoliberal policy and actually endorse market-based governance instruments like forest certification.

\subsection{Social Forestrty and Ecosystem Management, Conflicting Paradigms?}

The ENGOs associated with the environmental justice master frame endorse community-based forest management. Community-based forest management is associated with the social forestry paradigm [50]. Community forestry is a multi-faceted concept, and its actual meaning is highly context dependent [94]. In general, community forestry represents an umbrella term comprising various types of forestry (e.g., participation forestry, joint forest management, co-management) in which some level of responsibility and authority for forest management is formally transferred to local communities [50,95-97]. Community forestry has been primarily implemented in the Global South [50,94,97], but an increased level of interest in commons-based approaches to forest management has also been noted in Europe [98], the USA [47,99] and Canada [22].

The ENGOs associated with the environmental justice master frame support a small-scale, commons-centered approach to forest management, emphasize customary practices, and request a transition of decision-making power to local communities. As such, they promote a community forestry implemented based on power-sharing. Community forestry based on power-sharing represents a narrow interpretation of social forestry paradigm in which some degree of decision making power over forest management is transferred to local communities [95]. Benefit-sharing based community forestry is an alternative form in which local communities enjoy the benefits from forest management but do not have power over decision making [95].

On the contrary, the ENGOs associated with the environmentalist master frame, support a broad range of forest management approaches related to the ecosystem management and social forestry management paradigms that do not necessarily require a transfer of decision-making power to local communities. Moreover, the ENGOs associated with the environmentalist master frame strongly endorse FSC certification. However, any kind of forest certification is rejected by the ENGOs associated with the environmental justice master frame. 
Therefore, although the analyzed ENGOs support similar types of forest management, a gap also exists between the groups associated with different master frames. Our findings suggest that the level of power of local communities over the decision-making in forest management represents an emerging fault line along which future conflicts over forest management may be expected. Winkel [47] reached similar conclusions in his case study on forest governance in the Pacific Northwest region of the USA. The proponents of social forestry are increasingly challenging the dominance of the ecosystem management paradigm on federally owned forest lands in the USA [47].

\subsection{Concluding Remarks and Future Reaserch Needs}

In this study, we applied a frame analysis of ENGO press releases to explore differences in the conceptualizations of SFM expressed by an ENGO community. We identified two master frames: environmental justice and environmentalism. The identified differences in emphases on distributive and procedural justice as well as different standpoints regarding the commons versus commodity debate underpin the different conceptualizations of SFM. On the one hand, the ENGOs associated with the environmental justice master frame reject plantations and forest certification as sustainable sources of wood and advocate for the wider implementation of community forest management based on power-sharing. On the other hand, the ENGOs associated with the environmental justice master frame conditionally approve of the use of plantations as sustainable sources of timber, endorse FSC certification and, depending on the contextual factors, advocate for the use of a wide range of forest management practices associated with the ecosystem management and social forestry paradigm.

As with any scientific work, our work has its share of limitations. Frame analysis also represents a way how we frame our scientific investigation. An application of different scientific methods may shed an additional light on some aspects of the study. For example, Beland Lindahl [34] proposed an application of a place-based frame analysis to investigate how material aspects and place perceptions influence actor-specific framing. We did consider the geographical scope of the coded statements, however, due to the lack of statements addressing place perceptions, such an analysis was not possible. Another limitation emerges from our sampling approach. The snowball sampling is suitable for qualitative research [65]. However, the limitation is that the selection of the initial subjects and the selection of the subsequent subjects are not random [100]. Accordingly, our results cannot be generalized to a whole population. We minimized the impact of the limitations by conducting a query in the UN ECOSOC database to select the initial subjects.

In future research, it may be beneficial to carry out a more detailed analysis of ethical dimensions underpinning different concepts in forestry to gain a better understanding of the extant controversies in forest management. The meaning of concepts in natural resource management are known to be inherently vague due to the underdeveloped normative and ethical dimensions [101]. We have observed that many concepts with ambiguous meanings have prominent roles in the discourse of the analyzed ENGOs (e.g., working forests [102], forest-dependent peoples [103]). Moreover, the ENGOs associated with the environmentalist master frame endorse ecoforestry. However, ecoforestry is not a straightforward concept; it encompasses a broad spectrum of forest management approaches bound together by the common emphasis placed on natural patterns, processes and maintenance of their integrity [51]. The critical review from Batavia and Nelson illustrated how ethical and normative caveats in the common perception of ecoforestry enable potentially conflicting management actions to all be called ecoforestry [104]. Forestry scientists have only recently begun to explicitly consider the ethical assumptions that underpin new forest management concepts like systemic forestry [105]. In our study, ethical concerns regarding environmental justice play prominent roles. We illustrate how differently framing environmental injustice may influence different conceptualizations of SFM.

Moreover, all of the analyzed ENGOs commonly advocated the conservation of natural, virgin, ancient and primeval forests. However, the grounds for such propositions were often not provided or were based on a blanket assumption that natural forests have high levels of biodiversity. An automatic assumption that conditions perceived as natural are immediately desirable represents a naturalistic 
fallacy [30]. Also, natural forests may not always be rich in biodiversity [106]. We, therefore, agree with Batavia and Nelson $[104,107,108]$, who stated that an exploration of the ethical dimensions underpinning different forestry concepts may provide more conceptual and operational clarity for both forest managers and policy-makers.

The European definition of SFM represents an interesting case for such an analysis, because prominent European institutions have varying opinions as to whether and to which degree a European understanding of SFM aligns to an ecosystem management paradigm $[48,109]$. A comparison of the ecoforestry concept, which was coined in early 1990s in North America [51] with the European concept of "close-to-nature silviculture", which is more than a century old [110,111], represents another case for such a research.

Author Contributions: N.Š.: conceptualization, methodology, formal analysis, writing—original draft. F.H.: supervision, writing — review \& editing. T.S.: supervision, writing—review \& editing.

Funding: This work was supported by the Austrian Research Promotion Agency (FFG) under the COMET Program Grant Number 844608 . The article processing charges were funded by University of Graz.

Conflicts of Interest: The authors declare no conflict of interest. The funders had no role in the design of the study; in the collection, analyses, or interpretation of data; in the writing of the manuscript, and in the decision to publish the results.

\section{References}

1. Benson, M.H.; Craig, R.K. The End of Sustainability. Soc. Nat. Resour. 2014, 27, 777-782. [CrossRef]

2. Beckerman, W. "Sustainable development": Is it a useful concept? Environ. Values 1994, 3, 191-209. [CrossRef]

3. Wiersum, K.F. 200 years of sustainability in forestry: Lessons from history. Environ. Manag. 1995, 19, 321-329. [CrossRef]

4. Nylund, J.-E.; Kröger, M. Cleavage in the understanding of sustainability: Sustainable pulp industry versus sustained local livelihood. Scand. J. For. Res. 2012, 27, 229-240. [CrossRef]

5. Hahn, W.A.; Knoke, T. Sustainable development and sustainable forestry: Analogies, differences, and the role of flexibility. Eur. J. For. Res. 2010, 129, 787-801. [CrossRef]

6. Wang, S. One hundred faces of sustainable forest management. For. Policy Econ. 2004, 6, 205-213. [CrossRef]

7. Bringezu, S.; O'Brien, M.; Schütz, H. Beyond biofuels: Assessing global land use for domestic consumption of biomass. Land Use Policy 2012, 29, 224-232. [CrossRef]

8. O'Brien, M. Timber Consumption and Sustainable Forest Use Assessing the EU's Current and Expected Consumption of Global Timber in Relation to the Global Capacity for Sustainable Supply; Kassel University Press: Kassel, German, 2016; ISBN 978-3-7376-0150-4.

9. Winkel, G.; Gleißner, J.; Pistorius, T.; Sotirov, M.; Storch, S. The sustainably managed forest heats up: Discursive struggles over forest management and climate change in Germany. Crit. Policy Stud. 2011, 5, 361-390. [CrossRef]

10. Edwards, P.; Kleinschmit, D. Towards a European forest policy-Conflicting courses. For. Policy Econ. 2013, 33, 87-93. [CrossRef]

11. Korten, F.F. NGOs and the forestry sector: An overview. Unasylva 1992, 43, 3-10.

12. Betsill, M.M.; Corell, E. (Eds.) NGO Diplomacy: The Influence of Nongovernmental Organizations in International Environmental Negotiations; MIT Press: Cambridge, MA, USA, 2008; ISBN 978-0-262-02626-0.

13. Cashore, B. Legitimacy and the privatization of environmental governance: How non-state market-driven (NSMD) governance systems gain rule-making authority. Governance 2002, 15, 503-529. [CrossRef]

14. Schirmer, J. Environmental Activism and the Global Forest Sector. In The Global Forest Sector: Changes, Practices, and Prospects; Panwar, R., Vlosky, R., Hansen, E., Eds.; CRC Press: Boca Raton, FL, USA, 2013; pp. 203-237.

15. Tuppura, A.; Toppinen, A.; Puumalainen, K. Forest Certification and ISO 14001: Current State and Motivation in Forest Companies: Certification: Current State and Motivation in Forest Companies. Bus. Strateg. Environ. 2016, 25, 355-368. [CrossRef]

16. Johansson, J. Why do forest companies change their CSR strategies? Responses to market demands and public regulation through dual-certification. J. Environ. Plan. Manag. 2014, 57, 349-368. [CrossRef] 
17. Schlosberg, D. Defining Environmental Justice: Theories, Movements, and Nature; Oxford University Press: Oxford, UK, 2007.

18. Agyeman, J.; Evans, B. "Just sustainability": The emerging discourse of environmental justice in Britain? Geogr. J. 2004, 170, 155-164. [CrossRef]

19. Vermunt, R.; Törnblom, K. Introduction: Distributive and procedural justice. Soc. Justice Res. 1996, 9, 305-310. [CrossRef]

20. Valkeapää, A.; Karppinen, H. Citizens' view of legitimacy in the context of Finnish forest policy. For. Policy Econ. 2013, 28, 52-59. [CrossRef]

21. Vainio, A. Why are Forest Owners Satisfied with Forest Policy Decisions? Legitimacy, Procedural Justice, and Perceived Uncertainty. Soc. Justice Res. 2011, 24, 239-254. [CrossRef]

22. McCarthy, J. Neoliberalism and the Politics of Alternatives: Community Forestry in British Columbia and the United States. Ann. Assoc. Am. Geogr. 2006, 96, 84-104. [CrossRef]

23. Petrova, S. Contesting forest neoliberalization: Recombinant geographies of 'illegal' logging in the Balkans. Geoforum 2014, 55, 13-21. [CrossRef]

24. Bakker, K.J. Privatizing Water: Governance Failure and the World's Urban Water Crisis; Cornell University Press: Ithaca, NY, USA, 2010; ISBN 978-0-8014-4723-5.

25. McCarthy, J.; Prudham, S. Neoliberal nature and the nature of neoliberalism. Geoforum 2004, 35, $275-283$. [CrossRef]

26. Klooster, D. Standardizing sustainable development? The Forest Stewardship Council's plantation policy review process as neoliberal environmental governance. Geoforum 2010, 41, 117-129. [CrossRef]

27. Bakker, K. The "Commons" Versus the "Commodity": Alter-globalization, Anti-privatization and the Human Right to Water in the Global South. Antipode 2007, 39, 430-455. [CrossRef]

28. Foley, P.; Hébert, K. Alternative Regimes of Transnational Environmental Certification: Governance, Marketization, and Place in Alaska's Salmon Fisheries. Environ. Plan. A 2013, 45, 2734-2751. [CrossRef]

29. Knauf, M. Is the Sustainability Revolution Devouring Its Own Children? Understanding Sustainability as a Travelling Concept and the Role Played by Two German Discourses on Sustainability. Forests 2014, 5, 2647-2657. [CrossRef]

30. Nelson, M.P.; Vuchetich, J.A. Environmental ethics for wildlife management. In Human Dimensions of Wildlife Management; Johns Hopkins University: Baltimore, MD, USA, 2012.

31. Lindahl, K.B.; Westholm, E. Future forests: Perceptions and strategies of key actors. Scand. J. For. Res. 2012, 27, 154-163. [CrossRef]

32. Fischer, A.P.; Bliss, J.C. Framing Conservation on Private Lands: Conserving Oak in Oregon's Willamette Valley. Soc. Nat. Resour. 2009, 22, 884-900. [CrossRef]

33. Perri 6. What's in a frame? Social organization, risk perception and the sociology of knowledge. J. Risk Res. 2005, 8, 91-118. [CrossRef]

34. Beland Lindahl, K.; Baker, S.; Rist, L.; Zachrisson, A. Theorising pathways to sustainability. Int. J. Sustain. Dev. World Ecol. 2016, 23, 399-411. [CrossRef]

35. Goffman, E. Frame Analysis: An Essay on the Organization of Experience; Northeastern University Press, Ed.; Northeastern University Press: Boston, MA, USA, 1986; ISBN 978-0-930350-91-8.

36. Beland Lindahl, K. Frame Analysis, Place Perceptions and the Politics of Natural Resource Management: Exploring a Forest Policy Controversy in Sweden; Acta Universitatis Agriculturae Sueciae; Department of Urban and Rural Development, Swedish Univ. of Agricultural Sciences: Uppsala, Sweden, 2008; ISBN 978-91-85913-93-0.

37. Schön, D.; Rein, M. Frame Reflection: Toward the Resolution of Intractable Policy Controversies; Basic Books: New York, NY, USA, 1994.

38. Benford, R.D.; Snow, D.A. Framing processes and social movements: An overview and assessment. Annu. Rev. Sociol. 2000, 26, 611-639. [CrossRef]

39. Entman, R. Framing: Toward Clarification of a Fractured Paradigm. J. Commun. 1993, 51-58. [CrossRef]

40. Snow, D.; Benford, R. Master Frames and Cycles of Protest. In Frontiers in Social Movement Theory; Morris, A.D., McClurg Mueller, C., Eds.; Yale University Press: London, UK; New Haven, CT, USA, 1992; ISBN 978-0-300-05486-6.

41. Levinger, M.; Lytle, P.F. Myth and mobilisation: The triadic structure of nationalist rhetoric. Nations Natl. 2001, 7, 175-194. [CrossRef] 
42. Sjöstedt, V.; Kleinschmit, D. Frames in environmental policy integration: Are Swedish sectors on track? Environ. Plan. C Gov. Policy 2016, 34, 515-528. [CrossRef]

43. Sadath, N.; Kleinschmit, D.; Giessen, L. Framing the tiger-A biodiversity concern in national and international media reporting. For. Policy Econ. 2013, 36, 37-41. [CrossRef]

44. Caiani, M.; della Porta, D. The elitist populism of the extreme right: A frame analysis of extreme right-wing discourses in Italy and Germany. Acta Polit. 2011, 46, 180-202. [CrossRef]

45. Benford, R.D. Master Frame. In The Wiley-Blackwell Encyclopedia of Social and Political Movements; Wiley Blackwell Publishing: Malden, MA, USA, 2013; ISBN 978-0-470-67487-1.

46. Taylor, D.E. The Rise of the Environmental Justice Paradigm: Injustice Framing and the Social Construction of Environmental Discourses. Am. Behav. Sci. 2000, 43, 508-580. [CrossRef]

47. Winkel, G. When the pendulum doesn't find its center: Environmental narratives, strategies, and forest policy change in the US Pacific Northwest. Glob. Environ. Chang. 2014, 27, 84-95. [CrossRef]

48. European Environment Agency. European Forest Ecosystems: State and Trends; Publications Office: Luxembourg, 2016; ISBN 978-92-9213-728-1.

49. Salmon, G. Toward a strategic vision for forestry: The environmental and social context. N. Z. J. For. 2003, 48, 4-10.

50. Balooni, K.; Inoue, M. Decentralized Forest Management in South and Southeast Asia. J. For. 2007, 105, 414-420.

51. Seymour, R.S.; Hunter, M.L.J. Principles of ecological forestry. In Maintaining Biodiversity in Forest Ecosystems; Hunter, M.L., Ed.; Cambridge University Press: Cambridge, UK, 1999; pp. 22-62, ISBN 978-0-511-61302-9.

52. Catenaccio, P. Press releases as a hybrid genre: Addressing the informative/promotional conundrum. Pragmatics 2008, 18, 9-31. [CrossRef]

53. Maat, H.P. How Promotional Language in Press Releases Is Dealt With by Journalists: Genre Mixing or Genre Conflict? J. Bus. Commun. 2007, 44, 59-95. [CrossRef]

54. Gilpin, D.R. Narrating the organizational self: Reframing the role of the news release. Public Relat. Rev. 2008, 34, 9-18. [CrossRef]

55. Choi, J.; Lee, S. Managing a crisis: A framing analysis of press releases dealing with the Fukushima nuclear power station crisis. Public Relat. Rev. 2017, 43, 1016-1024. [CrossRef]

56. Vidal, N.G.; Bull, G.Q.; Kozak, R.A. Diffusion of Corporate Responsibility Practices to Companies: The Experience of the Forest Sector. J. Bus. Ethics 2010, 94, 553-567. [CrossRef]

57. Cannon, C. An overview of the Global Journal's Top 100 NGOs methodology in 2013. 2013. Available online: idsa02.pbworks.com/w / file/fetch/74298527/EvaluatingNGOs(MethodologyPaper)_EN.pdf (accessed on 13 June 2018).

58. Charnovitz, S. Two Centuries of Participation: NGOs and International Governance. Mich. J. Int. Law 1997, $18,105$.

59. UN ECOSOC. Report of the Intergovernmental Forum on Forests on Its Fourth Session; UN ECOSOC: New York, NY, USA, 2000.

60. UN ECOSOC. Establishment of an Ad Hoc Open-Ended Intergovernmental Forum on Forests; UN ECOSOC: New York, NY, USA, 1997.

61. UN. Working with ECOSOC, an NGO Guide to Consultative Status; NGO Branch of the UN-DESA: New York, NY, USA, 2011.

62. UN. United Nations Agenda 21; UN: New York, NY, USA, 1992.

63. Bäckstrand, K. Multi-stakeholder partnerships for sustainable development: Rethinking legitimacy, accountability and effectiveness. Eur. Environ. 2006, 16, 290-306. [CrossRef]

64. Dentoni, D.; Bitzer, V. The role(s) of universities in dealing with global wicked problems through multi-stakeholder initiatives. J. Clean. Prod. 2015, 106, 68-78. [CrossRef]

65. Bryman, A. Social Research Methods, 4th ed.; Oxford University Press: Oxford, UK; New York, NY, USA, 2012; ISBN 978-0-19-958805-3.

66. Johnston, H. Verification and proof in frame and discourse analysis. In Methods of Social Movement Research; Klandermans, B., Staggenborg, S., Eds.; University of Minnesota Press: Minneapolis, MN, USA, 2002.

67. Creswell, J.W. Qualitative Inquiry and Research Design Choosing among Five Traditions; SAGE: London, UK, 1998.

68. Löfmarck, E.; Uggla, Y.; Lidskog, R. Freedom with what? Interpretations of "responsibility" in Swedish forestry practice. For. Policy Econ. 2017, 75, 34-40. [CrossRef] 
69. Jensen, T.K.; Johnsen, T.J. Sundhedsfremme i teori och Praksis. En laere-, debat og Brugsbok pci Grundlag av teori och Praksisbeskrivelser; Sundhetsfremmeafdelningen, Ringkobing Amt: Ringkobing, Denmark, 2000.

70. Kvale, S. Doing Interviews; The Sage Qualitative Research Kit; SAGE Publications: London, UK, 2007; Volume 1, ISBN 978-0-7619-4977-0.

71. Day, D.M.; Page, S. Portrayal of Mental Illness in Canadian Newspapers. Can. J. Psychiatry 1986, 31, 813-817. [CrossRef] [PubMed]

72. World Rainforest Movement. WRM Statement: The Climate and Forest Crises Cannot be Solved with Number Games and False Solutions; World Rainforest Movement: Montevideo, Uruguay, 2016.

73. Friends of the Earth International. Forests Need Proper Definition, NGOs Tell FAO; Friends of the Earth International: Amsterdam, The Netherlands, 2014.

74. World Rainforest Movement. Greenwashing Continues: FSC Certifies Industrial Tree Plantations as Forests and RSPO Oil Palm Plantations as Sustainable; World Rainforest Movement: Montevideo, Uruguay, 2017.

75. World Rainforest Movement. International Campaign to Define Forests by Their True Meaning! World Rainforest Movement: Montevideo, Uruguay, 2014.

76. Friends of the Earth International. Karin Nansen, New Chair of Friends of the Earth International; Friends of the Earth International: Amsterdam, The Netherlands, 2017.

77. World Wildlife Fund for Nature. WWF Welcomes UN Report Underlining Symbiotic Relationship between People, Biodiversity and Sustainable Development; World Wildlife Fund for Nature: Gland, Switzerland, 2017.

78. World Wildlife Fund for Nature. Mondi and WWF Extend Strategic Partnership by Three Years; World Wildlife Fund for Nature: Gland, Switzerland, 2017.

79. Greenpeace. People All over the World Ask Essity to Stop Wiping Away the Great Northern Forest; Greenpeace: Amsterdam, The Netherlands, 2017.

80. The Nature Conservancy. New Study Finds Nature is Vital to Beating Climate Change; The Nature Conservancy: Arlington County, VA, USA, 2017.

81. Greenpeace. Major Breakthrough in Protection for Indonesia's Remaining Rainforests; Greenpeace: Amsterdam, The Netherlands, 2013.

82. The Global Forest Coalition. New Briefing Paper Highlights Dangers of a Fraudulent Accounting Framework on Land Use to Potential Climate Agreement; The Global Forest Coalition: Asunción, Paraguay, 2015.

83. World Rainforest Movement. Over 100 Organisations Call for an End to Biodiversity Offsetting Plans; World Rainforest Movement: Montevideo, Uruguay, 2013.

84. Friends of the Earth International. Brazil Frustrates California's Hopes for International Forest Carbon Offsets; Friends of the Earth International: Amsterdam, The Netherlands, 2015.

85. The Nature Conservancy. MEDIA ADVISORY COP22 Marrakech, 2016; The Nature Conservancy: Arlington County, VA, USA, 2016.

86. Greenpeace. Greenpeace Sails into Papua to Protect Rainforest 'Eden; Greenpeace: Amsterdam, The Netherlands, 2017.

87. World Wildlife Fund for Nature. "Remarkable Social Progress" When Forests Are FSC Certified-New Study Confirms; World Wildlife Fund for Nature: Gland, Switzerland, 2014.

88. World Wildlife Fund for Nature. FSC Certification in Cameroon Surpasses 1 Million Hectares; World Wildlife Fund for Nature: Gland, Switzerland, 2013.

89. World Wildlife Fund for Nature. UN Report Finds Deforestation Slowing, but Not Fast Enough for Forest Communities or the Climate; World Wildlife Fund for Nature: Gland, Switzerland, 2015.

90. Greenpeace. Agribusiness Companies Destroying Vital Rainforest Habitat of Chimpanzees and Other Great Apes; Greenpeace: Amsterdam, The Netherlands, 2015.

91. Sutterlüty, A.; Šimunović, N.; Hesser, F.; Stern, T.; Schober, A.; Schuster, K.C. Influence of the geographical scope on the research foci of sustainable forest management: Insights from a content analysis. For. Policy Econ. 2018, 90, 142-150. [CrossRef]

92. Han, X.; Hansen, E. Corporate Social Responsibility Implementation in the Global Forest Sector. J. Corp. Citizsh. 2012, 2012, 101-118. [CrossRef]

93. Ranängen, H.; Zobel, T. Revisiting the 'how' of corporate social responsibility in extractive industries and forestry. J. Clean. Prod. 2014, 84, 299-312. [CrossRef]

94. Glasmeier, A.K.; Farrigan, T. Understanding community forestry: A qualitative meta-study of the concept, the process, and its potential for poverty alleviation in the United States case. Geogr. J. 2005, 171, 56-69. [CrossRef] 
95. Charnley, S.; Poe, M.R. Community Forestry in Theory and Practice: Where Are We Now? Annu. Rev. Anthropol. 2007, 36, 301-336. [CrossRef]

96. Dove, M.R. The theory of social forestry intervention: The state of the art in Asia. Agrofor. Syst. 1995, 30, 315-340. [CrossRef]

97. Burivalova, Z.; Hua, F.; Koh, L.P.; Garcia, C.; Putz, F. A Critical Comparison of Conventional, Certified, and Community Management of Tropical Forests for Timber in Terms of Environmental, Economic, and Social Variables: Certified and community forest management. Conserv. Lett. 2017, 10, 4-14. [CrossRef]

98. Wiersum, K.F.; Singhal, R.; Benneker, C. Common property and collaborative forest management: rural dynamics and evolution in community forestry regimes. For. Trees Livelihoods 2004, 14, 281-293. [CrossRef]

99. Maier, C.; Abrams, J.B. Navigating social forestry-A street-level perspective on National Forest management in the US Pacific Northwest. Land Use Policy 2018, 70, 432-441. [CrossRef]

100. Heckathorn, D.D.; Cameron, C.J. Network Sampling: From Snowball and Multiplicity to Respondent-Driven Sampling. Annu. Rev. Sociol. 2017, 43, 101-119. [CrossRef]

101. Dietz, T. What is a Good Decision? Criteria for Environmental Decision Making. Hum. Ecol. Rev. 2003, 10, 7.

102. Wolf, S.A.; Klein, J.A. Enter the working forest: Discourse analysis in the Northern Forest. Geoforum 2007, 38, 985-998. [CrossRef]

103. Newton, P.; Miller, D.C.; Byenkya, M.A.A.; Agrawal, A. Who are forest-dependent people? A taxo nomy to aid livelihood and land use decision-making in forested regions. Land Use Policy 2016, 57, 388-395. [CrossRef]

104. Batavia, C.; Nelson, M.P. Conceptual Ambiguities and Practical Challenges of Ecological Forestry: A Critical Review. J. For. 2016, 114, 572-581. [CrossRef]

105. Nocentini, S.; Buttoud, G.; Ciancio, O.; Corona, P. Managing forests in a changing world: The need for a systemic approach. A review. For. Syst. 2017, 26, eR01. [CrossRef]

106. European Environment Agency. Developing a Forest Naturalness Indicator for Europe: Concept and Methodology for a High Nature Value (HNV) Forest Indicator; Publications Office: Luxembourg, 2014; ISBN 978-92-9213-478-5.

107. Batavia, C.; Nelson, M.P. The Logical and Practical Necessity of Ethics in Ecological Forestry: A Reply to Palik and D'Amato 2016. J. For. 2017, 115, 56-57. [CrossRef]

108. Batavia, C.; Nelson, M.P. Translating climate change policy into forest management practice in a multiple-use context: The role of ethics. Clim. Chang. 2018. [CrossRef]

109. Ministerial Conference on the Protection of Forests in Europe; Liaison Unit Warsaw. Joint Position of the MCPFE and the EfE/PEBLDS on the Pan-European Understanding of the Linkage between the Ecosystem Approach and Sustainable Forest Management; Ministerial Conference on the Protection of Forests in Europe; Joint Secretariat of the Pan-European Biological and Landscape Diversity Strategy; Council of Europe: Warsaw, Poland; Geneva, Switzerland; Strasbourg, France, 2006; ISBN 978-83-922396-2-8.

110. Gayer, K. Der Gemischte Wald: Seine Begründung und Pflege, Insbesondere durch Horst- und Gruppenwirtschaft; Paul Parey: Berlin, German, 1886.

111. Brang, P.; Spathelf, P.; Larsen, J.B.; Bauhus, J.; Bonccina, A.; Chauvin, C.; Drossler, L.; Garcia-Guemes, C.; Heiri, C.; Kerr, G.; et al. Suitability of close-to-nature silviculture for adapting temperate European forests to climate change. Forestry 2014, 87, 492-503. [CrossRef]

(C) 2018 by the authors. Licensee MDPI, Basel, Switzerland. This article is an open access article distributed under the terms and conditions of the Creative Commons Attribution (CC BY) license (http:// creativecommons.org/licenses/by/4.0/). 